Journal of Clinical Investigation

Vol. 41, No. 12, 1962

\title{
CHRONIC UNCONJUGATED HYPERBILIRUBINEMIA WITHOUT OVERT SIGNS OF HEMOLYSIS IN ADOLESCENTS AND ADULTS *
}

\author{
BY IRWIN M. ARIAS $\dagger$ \\ (From the Department of Medicine, Albert Einstein College of Medicine, and The Bronx \\ Municipal Hospital Center, New York, N. Y.)
}

(Submitted for publication June 11, 1962; accepted September 1, 1962)

The syndrome of chronic unconjugated hyperbilirubinemia without overt signs of hemolysis in adolescents and adults has been variously termed cholémie simple familiale (Gilbert's disease) (1), icterus intermittens juvenilis (2), hereditary nonhemolytic bilirubinemia (3), familial nonhemolytic jaundice (4), physiologic hyperbilirubinemia (5), and constitutional hepatic dysfunction (6). These terms neither adequately describe the pathophysiology nor indicate the heterogeneity of cases with chronic jaundice of this type.

The present report is a study of 23 adolescent and adult patients with chronic unconjugated hyperbilirubinemia without overt signs of hemolysis, and of their families. The object of the study was to determine the pathogenesis of chronic jaundice of this type.

The metabolism of bilirubin by the liver, reviewed elsewhere ( 7$)$, involves three major processes : 1) the transfer of bilirubin from plasma into the liver cell, 2) the intracellular formation of bilirubin conjugates, and 3 ) the excretion of the water-soluble bilirubin conjugates into the bile. Very little is known about the mechanism and regulation of the first and third of these processes. The conjugation of bilirubin, primarily with glucuronic acid, but also with sulfate and other as yet unidentified substances, converts bilirubin to more water-soluble bilirubin conjugates $(8-11)$. In the formation of glucuronides, the transfer of glucuronic acid from uridine diphosphate glucuronic acid (UDPGA) to suitable receptors such as bilirubin, phenols, acids, various steroids, and alcohols is catalyzed by glucuronyl transferase, an enzyme associated with the microsomal fraction of homogenates of mammalian liver (12-16). Con-

\footnotetext{
* Work supported in part by U. S. Public Health Service Research Grant A-2019.

$\dagger$ Senior Research Fellow, New York Heart Association and Heart Fund, Inc.
}

jugation is required for the excretion of bilirubin into the bile and urine $(17,18)$.

Chronic unconjugated hyperbilirubinemia theoretically may result from one or more of the following mechanisms: 1) increased production of bile pigment, 2) impaired transfer of unconjugated bilirubin from plasma into the liver cell, and 3 ) defective conversion of unconjugated bilirubin to bilirubin glucuronide, the major bilirubin conjugate. Each of these aspects of bilirubin metabolism was investigated in each of the 23 patients.

\section{METHODS}

Patients were selected for study upon the demonstration of chronic unconjugated hyperbilirubinemia in the absence of anemia, reticulocytosis, bilirubinuria, and hepatic or splenic enlargement. One hundred twentythree grandparents, parents, siblings, children, aunts, uncles, and first cousins were also studied.

1) Serum bilirubin concentration was estimated by the Malloy-Evelyn modification of the van den Bergh reaction (19). In nine cases bile was obtained either by duodenal intubation or by aspiration of the gall bladder at surgery. After addition of diazotized sulphanilic acid to serum and bile, concentrations of unconjugated and conjugated dipyrrolazo pigments-pigments $\mathrm{A}$ and $\mathrm{B}$, respectively-were estimated (20). The proportion of pigment B present as a glucuronide was calculated after estimation of the amount converted to pigment $\mathrm{A}$ by alkaline or beta glucuronidase hydrolysis. Bilirubin was identified in the urine by the Fouchet reaction.

2) Studies of the production of bile pigment. a) $\mathrm{He}-$ moglobin concentration, red blood cell count, hematocrit, reticulocyte count, and erythrocyte sedimentation rate were estimated in each patient by conventional techniques, and the cellular morphology of the peripheral blood and bone marrow was examined. Osmotic fragility of erythrocytes was estimated in four cases, and a Coombs test was performed in four. b) Erythrocyte survival was studied in 21 patients by the $\mathrm{Cr}^{51}$-labeling technique of Mollison and Veal (21). c) Quantitative 24-hour urinary urobilinogen excretion was estimated in each patient by the method of Watson, Schwartz, Soborov, and Bertie (22). d) Quantitative fecal urobilinogen excre- 
tion was estimated in 22 patients by the method of Watson and colleagues (22) on 3-day stool collections.

3) Studies of the transport of unconjugated bilirubin from plasma proteins into the liver cell. a) Serum obtained from pregnant women and newborn infants inhibits the formation of bilirubin glucuronide by rat liver slices more than it does that by rat liver homogenates (23-25). Lathe and Walker (23) suggest that the inhibitor primarily affects the uptake of bilirubin by the liver cells. Assay of serum inhibitor factor activity was performed in each of the 23 cases by the method of Lathe and Walker (23). b) The relative amounts of bilirubin glucuronide and 4-methyl umbelliferone (4-methyl 7-hydroxycoumarin) glucuronide formed by liver slices and homogenates from three patients and six control subjects were estimated by techniques to be described in the following section. Bilirubin and 4-methyl umbelliferone were separately suspended in the patient's serum and in pooled normal human serum, and incubated with UDPGA and liver slices and homogenates.

4) Studies of glucuronide formation. a) In vivo study of glucuronide formation was performed as follows. After a 10-hour fast, 22 of the patients, 28 members of their families, and 18 control subjects ingested $1 \mathrm{~g}$ of menthol, and the percentage of administered menthol excreted in the urine as menthol glucuronide during the subsequent 5 hours was estimated (26). The test was performed in each of the 22 patients on two separate occasions.

b) In vitro assay of hepatic glucuronyl transferase activity was performed with different glucuronide receptors. When liver specimens were obtained at surgery, their ability to form bilirubin and $o$-aminophenol glucuronides was quantified by methods described elsewhere $(15,27)$. When liver specimens weighing approximately 10 to $45 \mathrm{mg}$ were obtained with either the Vim-Silverman or Menghini needle, 4-methyl umbelliferone, which is highly fluorescent, served as a glucuronide receptor. All subsequent operations were performed at $-2^{\circ} \mathrm{C}$ unless otherwise noted. The liver specimens were immedi-

TABLE I

Glucuronyl transferase activity in separate liver specimens from control subjects*

\begin{tabular}{|c|c|c|c|c|c|c|}
\hline \multirow{2}{*}{$\begin{array}{c}\begin{array}{c}\text { Control } \\
\text { subject }\end{array} \\
1\end{array}$} & \multicolumn{5}{|c|}{ Units of glucuronyl transferase activity } & \multirow{2}{*}{$\frac{\text { Mean }}{213}$} \\
\hline & 201 & 194 & 232 & 214 & 224 & \\
\hline 2 & 248 & 198 & 236 & 229 & 240 & 230 \\
\hline 3 & 192 & 221 & 199 & 227 & & 209 \\
\hline 4 & 180 & 194 & 201 & 214 & & 197 \\
\hline 5 & 240 & 218 & 224 & 231 & & 228 \\
\hline 6 & 190 & 182 & 223 & & & 198 \\
\hline 7 & 200 & 239 & 220 & 234 & & 223 \\
\hline 8 & 198 & 216 & 206 & & & 207 \\
\hline 9 & 208 & 227 & & & & 217 \\
\hline
\end{tabular}

* Obtained at surgery, and incubated as described in the text.

$\dagger$ Unit $=$ activity of $1 \mathrm{mg}$ protein nitrogen catalyzing the formation of $1 \mathrm{~m} \mu$ mole of 4 -methyl umbelliferone glucuronide. ately placed in 0.25 to $1.0 \mathrm{ml}$ of $0.25 \mathrm{M}$ sucrose at $\mathrm{pH}$ 7.6 in a motor-driven Thomas homogenizer and rapidly homogenized for approximately 30 seconds. The protein concentration was estimated by ultraviolet absorption (28) and the homogenates were diluted with buffered $0.25 \mathrm{M}$ sucrose to yield a protein concentration of 20 to $50 \mathrm{mg}$ per $\mathrm{ml}$. The protein nitrogen content of the diluted homogenates was subsequently estimated by the Kjeldahl procedure (29). Samples of homogenate containing from 2 to $5 \mathrm{mg}$ of protein were used in the assay because greater amounts of protein quenched the fluorescence of 4-methyl umbelliferone. The samples were incubated for 30 minutes at $37^{\circ} \mathrm{C}$ in air with shaking at 92 cycles per minute with $0.5 \mathrm{M}$ Tris buffer at $\mathrm{pH} 7.8$, $0.2 \mu$ mole UDPGA, $500 \mu$ moles $\mathrm{MgCl}_{2}$, and $0.3 \mu$ mole 4-methyl umbelliferone, in a total volume of $2.5 \mathrm{ml}$. The incubation mixture was then shaken vigorously for 10 minutes with $15 \mathrm{ml}$ of chloroform three times to denature the protein and to extract unconjugated, but not conjugated, 4-methyl umbelliferone. The chloroform extracts were discarded. Samples of 0.5 to $1.0 \mathrm{ml}$ of the extracted incubation mixture were then incubated in air at $37^{\circ} \mathrm{C}$ with shaking at 92 cycles per minute with $0.35 \mathrm{M}$ Tris buffer at $\mathrm{pH} 7.0$ and $75 \mathrm{U}$ of bacterial beta glucuronidase (Sigma lot no. 105-8) in a total volume of $2.5 \mathrm{ml}$ for 90 minutes. Control flasks contained samples of the incubation mixture and were similarly incubated without the addition of beta glucuronidase. Five $\mathrm{ml}$ of $0.5 \mathrm{M}$ glycine buffer at $\mathrm{pH} 10.32$ was then added to the control and test flasks. The optimal $\mathrm{pH}$ for the fluorimetric estimation of 4-methyl umbelliferone is 10.32 . Fluorescence was then estimated at $460 \mathrm{~m} \mu$ with an activating maximum of 375 $\mathrm{m} \mu$ and compared with the fluorescence observed in the control flasks. The increase in fluorescence after the addition of beta glucuronidase was considered to represent the amount of 4-methyl umbelliferone formed in the original incubation medium.

The identity of the nonfluorescent conjugate formed was established by comparing its migration with that of standard 4-methyl umbelliferone glucuronide on paper chromatograms in several solvent systems: i) neutral ammonium acetate: ethanol $1: 1$, Rf umbelliferone 0.30 , umbelliferone glucuronide 0.90 ; ii) benzene: butanol: pyridine: water $1: 5: 3: 3$, Rf umbelliferone 0.80 , umbelliferone glucuronide 0.29 ; and $i i$ ) ammonium sulfate: ethanol : propionic acid $6: 5: 1$, Rf umbelliferone 0.63 , umbelliferone glucuronide 0.10 . Paper chromatograms were sprayed with bacterial beta glucuronidase, $75 \mathrm{U}$ per $\mathrm{ml}$ of $0.5 \mathrm{M}$ Tris buffer at $\mathrm{pH} 7.0$, and fluorescence was restored after incubation at $37^{\circ} \mathrm{C}$ for 2 hours as 4-methyl umbelliferone glucuronide was hydrolyzed on the paper.

From 85 to 100 per cent of 4-methyl umbelliferone was recovered after incubation of 0.05 to $1.00 \mu \mathrm{M} 4$-methyl umbelliferone glucuronide in $0.35 \mathrm{mM}$ Tris buffer at $\mathrm{pH}$ 7.0 with $75 \mathrm{U}$ of bacterial beta glucuronidase (Sigma lot no. 105-8) in a total volume of $2.5 \mathrm{ml}$ for 90 minutes at $37^{\circ} \mathrm{C}$.

Glucuronyl transferase activity was assayed in duplicate by this method in specimens of liver obtained by 


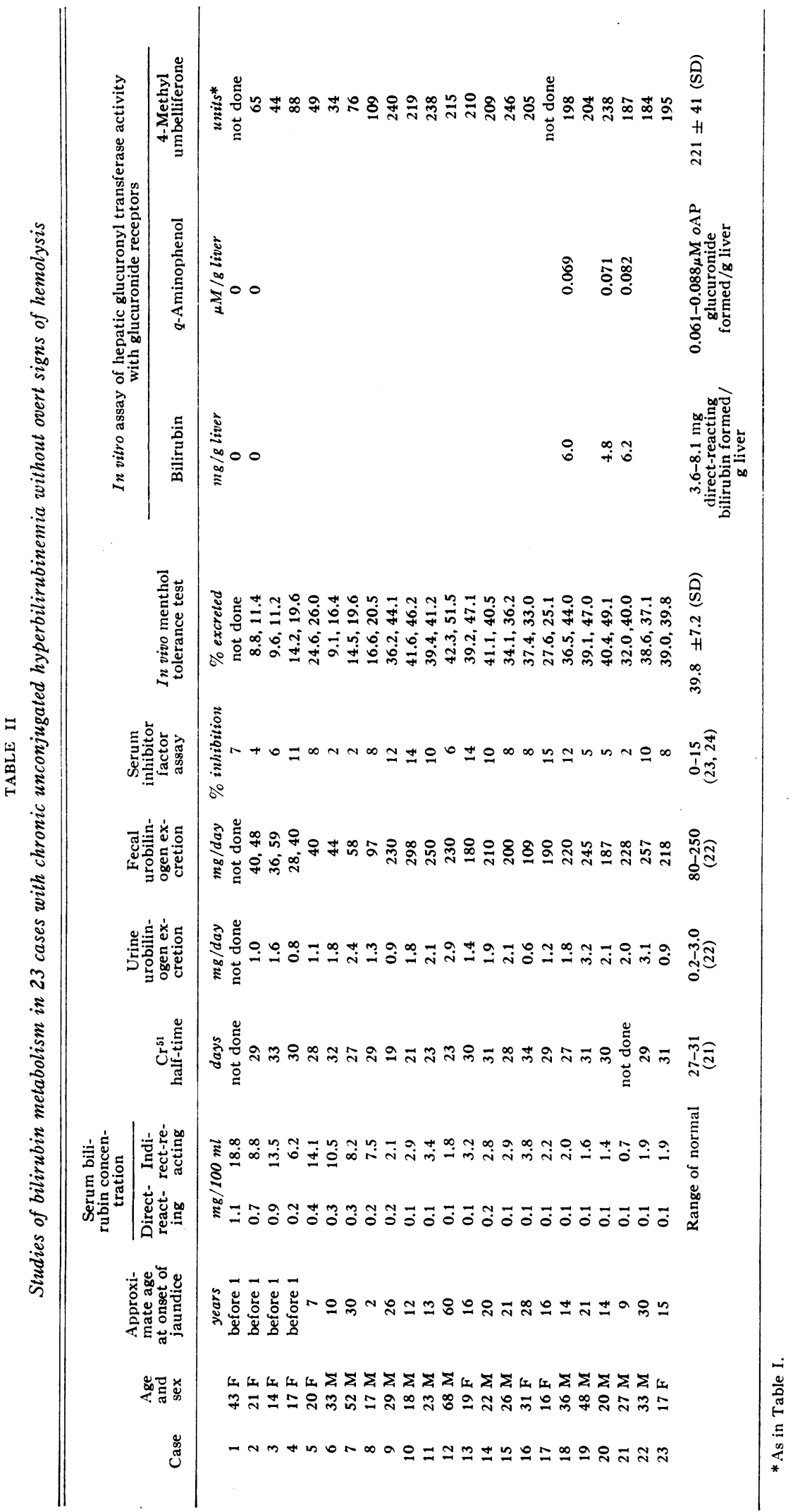


TABLE III

Scrum bilirubin concentrations in 23 adolescent and adul cases with chronic unconjugated hyperbilirubinemia without overt signs of hemolysis

\begin{tabular}{|c|c|c|c|c|}
\hline Case & $\begin{array}{l}\text { Number } \\
\text { of esti- } \\
\text { mations } \\
\text { of serum } \\
\text { bilirubin } \\
\text { concen- } \\
\text { trations }\end{array}$ & $\begin{array}{l}\text { Time } \\
\text { span of } \\
\text { estima- } \\
\text { tions }\end{array}$ & $\begin{array}{l}\text { Range in } \\
\text { serum bili- } \\
\text { rubin con- } \\
\text { centration }\end{array}$ & $\begin{array}{l}\text { Mean } \\
\text { estimate } \\
\text { of serum } \\
\text { bilirubin } \\
\text { concen- } \\
\text { tration }\end{array}$ \\
\hline 1/M.S. & $*$ & $\begin{array}{c}\text { years } \\
*\end{array}$ & $\begin{array}{c}m g / 100 \mathrm{ml} \\
16.0-22.0\end{array}$ & $\begin{array}{c}m g / 100 \mathrm{ml} \\
18.2\end{array}$ \\
\hline $2 /$ B.H. & 22 & 4 & $7.9-10.1$ & 8.8 \\
\hline 3/P.H. & 15 & 6 & $10.4-14.2$ & 11.7 \\
\hline 4/N.H. & 28 & 5 & $6.1-8.4$ & 7.9 \\
\hline 5/V.H. & 11 & 4 & $12.2-15.6$ & 13.6 \\
\hline $6 /$ H.J. & 13 & 3 & $7.4-11.6$ & 9.8 \\
\hline 7/R.J. & 8 & 4 & $5.8-12.9$ & 8.5 \\
\hline 8/J.A. & 15 & 4 & $7.9-10.8$ & 8.3 \\
\hline $9 /$ R.B. & 6 & 2 & $0.3-2.3$ & 1.9 \\
\hline 10/W.B. & 21 & 3 & $1.2-3.0$ & 2.5 \\
\hline $11 / \mathrm{J} . \mathrm{M}$ & 9 & 4 & $0.8-4.6$ & 2.2 \\
\hline 12 /S. B. & 11 & 3 & $0.6-2.9$ & 2.1 \\
\hline 1.3/M.M. & 9 & 2 & $0.4-4.0$ & 1.9 \\
\hline 14/P.K. & 12 & 1.5 & $0.4-3.0$ & 2.6 \\
\hline $15 / \mathrm{J} . \mathrm{G}$. & 11 & 2 & $0.9-3.5$ & 1.6 \\
\hline 16/G.L. & 6 & 1 & $3.1-4.1$ & 3.6 \\
\hline $17 /$ R.II. & 19 & 4 & $1.1-3.6$ & 2.5 \\
\hline 18/J.X. & 12 & 3 & $1.9-2.9$ & 2.1 \\
\hline 19/H.K. & 14 & 4 & $0.5-2.6$ & 1.4 \\
\hline 20/R.M. & 6 & 4 & $1.2-1.6$ & 1.3 \\
\hline 21/P.R. & 8 & 3 & $0.7-2.6$ & 1.6 \\
\hline $22 /$ R.T. & 16 & 4 & $1.1-3.4$ & 2.3 \\
\hline 23/R.R. & 11 & 4 & $0.8-2.8$ & 1.4 \\
\hline
\end{tabular}

* Serum bilirubin concentration ranged from 16.0 to 22.0 after repeated estimations were made during a 20-year period (32).

aspiration biopsy from 22 of the patients and one nonjaundiced family member. Assays were also performed in specimens of liver obtained from 24 control subjects at elective surgery for diseases not involving the liver or biliary system. The mean glucuronyl transferase activity was $221 \pm 41$ (SD) units in the control group. A unit has been arbitrarily defined as the activity of $1 \mathrm{mg}$ of protein nitrogen catalyzing the formation of $1 \mathrm{~m} \mu \mathrm{mole}$ of 4-methyl umbelliferone glucuronide.

To evaluate further the reproducibility of the method, from two to five separate liver biopsies were obtained by aspiration at surgery in nine of the control subjects. Each specimen was separately homogenized, glucuronyl transferase activity was assayed as described, and the mean enzyme activity for each subject was determined (Table I). Only three of the 34 estimations exceeded a SD of 20 units for each individual, which is half the $\mathrm{SD}$ observed in the control group.

5) Additional studies. a) Serum thymol turbidity, cephalin cholesterol flocculation, prothrombin time, alkaline phosphatase activity, glutamic-pyruvic transaminase activity, glutamic-oxaloacetic transaminase activity, protein electrophoresis, and concentration of cholesterol, cholesterol esters, albumin, glubulin, and iron were estimated by standard methods. Bromsulphalein retention was estimated 45 minutes after the intravenous administration of $5 \mathrm{mg}$ bromsulphalein per $\mathrm{kg}$ of body weight. b) A biopsy of liver was obtained either at surgery or by aspiration in 22 of the patients and was stained with hematoxylin and eosin. In seven cases, liver specimens obtained by aspiration biopsy were subjected to the following staining reactions (30): oil red orange, ATPase, acid phosphatase, alkaline phosphatase, lactic dehydrogenase, DPNH cytochrome $\mathrm{C}$ reductase, and 5-nucleotidase. Liver biopsy specimens from six cases were examined in the electron microscope. c) An upper gastrointestinal roentgenographic series and oral cholecystography or intra-

TABLE IV

Direct-reacting bilirubin and 4-methyl umbelliferone glucuronide formation by liver slices and homogenates from normal subjects and from cases 18,20 , and 21 , and incubated in pooled normal serum and in the patient's serum

\begin{tabular}{|c|c|c|c|c|c|c|c|c|}
\hline \multirow{3}{*}{$\begin{array}{c}\text { Tissue preparation: } \\
\text { Glucuronide receptor: } \\
\text { Source of added serum : } \ddagger\end{array}$} & \multicolumn{4}{|c|}{ Liver slices } & \multicolumn{4}{|c|}{ Liver homogenates } \\
\hline & \multicolumn{2}{|c|}{ Bilirubin* } & \multicolumn{2}{|c|}{$\begin{array}{l}\text { 4-Methyl umbelli- } \\
\text { feronet }\end{array}$} & \multicolumn{2}{|c|}{ Bilirubin } & \multicolumn{2}{|c|}{$\begin{array}{l}\text { 4-Methyl umbelli- } \\
\text { ferone }\end{array}$} \\
\hline & $\begin{array}{l}\text { Normal } \\
\text { subject }\end{array}$ & Patient & $\begin{array}{l}\text { Normal } \\
\text { subject }\end{array}$ & Patient & $\begin{array}{l}\text { Normal } \\
\text { subject }\end{array}$ & Patient & $\begin{array}{l}\text { Normal } \\
\text { subject }\end{array}$ & Patient \\
\hline \multicolumn{9}{|l|}{ Source of liver: } \\
\hline $\begin{array}{l}\text { Control subjects } \\
\text { (number of subjects } \\
\text { in parenthesis) }\end{array}$ & $\begin{array}{l}4.4- \\
6.4 \\
\quad(6)\end{array}$ & & $\begin{array}{l}137- \\
190 \\
(5)\end{array}$ & & $\begin{array}{l}5.8- \\
7.9 \\
(4)\end{array}$ & & $\begin{array}{l}158- \\
267 \\
(6)\end{array}$ & \\
\hline \multicolumn{9}{|l|}{$\begin{array}{l}\text { Patients with chronic } \\
\text { unconjugated hyper- } \\
\text { bilirubinemia } \|\end{array}$} \\
\hline $\begin{array}{l}\text { Case } 18 \\
\text { Case } 20 \\
\text { Case } 21\end{array}$ & $\begin{array}{l}5.4 \\
4.9 \\
5.8\end{array}$ & $\begin{array}{l}5.8 \\
5.4 \\
7.1\end{array}$ & $\begin{array}{l}159 \\
195 \\
143\end{array}$ & $\begin{array}{l}164 \\
180 \\
161\end{array}$ & $\begin{array}{l}6.0 \\
4.8 \\
6.2\end{array}$ & $\begin{array}{l}6.2 \\
6.1 \\
7.0\end{array}$ & $\begin{array}{l}156 \\
140 \\
209\end{array}$ & $\begin{array}{l}166 \\
249 \\
228\end{array}$ \\
\hline
\end{tabular}

* Method of Lathe and Walker (17); expressed as $\mu \mathrm{g}$ of direct-reacting bilirubin formed per $100 \mathrm{mg}$ liver.

$\dagger$ Expressed in units; 1 unit $=\mathrm{m} \mu$ moles of 4-methyl umbelliferone glucuronide formed by $1 \mathrm{mg}$ nitrogen.

$\ddagger$ Protein concentrations in each specimen were comparable. A correction was made for bilirubin present in serum from patients.

\$ Obtained at surgery for diseases not involving the liver or upper abdomen.

II Obtained at surgery for diagnostic exploration. 
venous cholangiography were performed in each patient, with appropriate contrast media.

6) Family studies. A medical history was obtained from each of the available 123 relatives of the 23 patients, and a physical examination was performed. A complete blood count, serum cephalin cholesterol flocculation, and estimation of the serum bilirubin concentration were performed in each of the available relatives. In selected subjects, the following studies were performed: $i$ ) oral menthol tolerance test, $i i)$ in vitro assay of hepatic glucuronyl transferase activity with specimens of liver obtained by aspiration biopsy and with 4-methyl umbelliferone as a glucuronide receptor, and iii) intravenous bilirubin tolerance test by the procedure described by With (31).

\section{RESULTS AND DISCUSSION}

In the following presentation, the cases are subdivided on the basis of demonstrable pathophysiologic abnormalities. The data are presented in Tables II, III, and IV.

\section{A. Patients with defective glucuronide formation (Cases 1-8)}

1) Clinical observations. Five of the eight cases were female, ranging in age from 14 to 52 years at the time of examination. Jaundice was first noted in four cases within the first year of life, and at age 2, 7,10, and 30 years in the remaining four cases. Jaundice of the skin, sclerae, and mucous membranes was the only abnormal finding on physical examination, with the exception of Case 1 , who showed idiocy and neurologic disability resulting from kernicterus (32). The other patients complained of intermittent easy fatigability, but were able to work or study, and, except for the social difficulties imposed by chronic jaundice, led a relatively normal life.

2) Serum bilirubin concentrations. The serum total bilirubin concentrations at the time of study ranged from 6.4 to $19.9 \mathrm{mg}$ per cent. The concentration of bilirubin in the serum that gave the direct van den Bergh reaction did not exceed 10 per cent of the total bilirubin concentration. A small fraction of unconjugated bilirubin can react with diazotized sulphanilic acid in the absence of alcohol, probably owing to the presence of bile acids, urea, albumin, and other substances in serum that facilitate the solubility of unconjugated bilirubin without the addition of alcohol (31). After the addition of diazotized sulphanilic acid to serum from each of the patients and after pa- per chromatography of the resulting dipyrrolazo pigments, only unconjugated dipyrrolazo pigment, pigment $A$, was demonstrated. This observation indicated that most if not all of the bilirubin in the sera was in the unconjugated form. The presence of small amounts of conjugated bilirubin cannot be excluded by this method.

The ranges observed in the serum bilirubin concentrations during periods of 3 to 20 years are presented in Table III. In most patients with nonhemolytic acholuric jaundice, the concentration of unconjugated bilirubin in the serum does not chronically exceed approximately five $\mathrm{mg}$ per cent, and hyperbilirubinemia is often intermittent $(1-6$, $33,34)$. Adolescents and adults with chronic unconjugated hyperbilirubinemia of the degree manifested by Cases 1 through 8 are rarely encountered $(3,4,35,36)$. The comparatively large number of such cases in this report results from efforts to obtain patients with marked jaundice of this type for study.

Several patients observed that exercise, fatigue, and consumption of alcohol were associated with an increase in clinical jaundice. A systematic examination of this observation was not made. Cases 2 and 4 walked from 5 to 10 miles on a treadmill in 1 to 2 hours and became considerably fatigued. There was no significant difference in the concentration of bilirubin in the serum obtaiiied immediately before, just after, and 24 and 48 hours after exercise. Case 6 voluntarily ingested ten ounces of whiskey; 24 hours later, the concentration of bilirubin in the serum was $12.1 \mathrm{mg}$ per cent, which represented an increase of $1.6 \mathrm{mg}$ per cent over control values.

Case 2 was observed during an episode of viral pneumonia. The serum total bilirubin concentration was $8.7 \mathrm{mg}$ per cent 1 week before the illness and did not change by more than $1.0 \mathrm{mg}$ per cent in ten determinations performed during the course of the acute illness.

3) Studies of the production of bile pigment. Hematologic studies including erythrocyte surrival and quantitative urinary urobilinogen excretion were normal when they were performed. Quantitative fecal urobilinogen excretion was reduced in Cases 2 through 7 to between 28 and 59 mg per day and to within normal limits in Case 8.

4) Assay of serum inhibitor factor activity. No sera from patients inhibited the formation of di- 
rect-reacting bilirubin by rat liver slices more than did sera from control subjects $(23,24)$.

5) Studies of glucuronide formation. Cases 2 through 8 excreted from 8.8 to 26.0 per cent of ingested menthol in the urine as menthol glucuronide in the subsequent 5 hours, and 18 control subjects excreted $39.8 \pm 7.2$ per cent (SD) in a similar time. By $t$ test (37), the difference between the results obtained in each patient and the mean in the control group is significant at the $p<0.001$ level of confidence.

Hepatic glucuronyl transferase activity was significantly reduced in Cases 1 through 8 . In Cases 2 through 8, 4-methyl umbelliferone was used as the glucuronide receptor, and hepatic glucuronyl transferase activity ranged from 34 to $109 \mathrm{U}$ as compared with the mean estimate of $221 \pm 41$ (SD) $\mathrm{U}$ in the control group. In Cases 1 and 2, hepatic glucuronyl transferase activity was estimated in specimens of liver obtained at surgery (15). Homogenates or microsomal preparations of the patients' livers were unable to form glucuronides of bilirubin or $o$-aminophenol when incubated with a boiled liver extract which possessed UDPGA activity, and these homogenates did not inhibit glucuronide formation by those of normal rat liver (15). In Case 2, hepatic glucuronyl transferase activity was subsequently assayed with 4-methyl umbelliferone as the glucuronide receptor in a liver specimen obtained by aspiration biopsy. Glucuronyl transferase activity was $65 \mathrm{U}$, or less than 30 per cent of the mean activity in the control group.

The UDPGA contents of boiled extracts of liver specimens obtained from Cases 1 and 2 appeared to be within normal limits (15).

Bile was obtained by aspiration of the gall bladder at surgery in Case 1 and by duodenal intubation in Cases 3,6, and 7. After addition of diazotized sulphanilic acid and then paper chromatography, pigment $\mathrm{B}$ was found to account for 65 to 85 per cent of the total dipyrrolazo pigments. From 70 to 100 per cent of pigment $B$ was converted to pigment $A$ after alkaline or beta glucuronidase hydrolysis. These observations are within the range of normal as observed in the study of nine bile samples obtained by similar methods from patients with no demonstrable liver or bilary tract disease (38).

6) Additional studies. Results of liver function tests were within normal limits. The histologic appearance of hematoxylin and eosin-stained sections of liver was normal except for the presence of bile pigment within Kupffer cells. Histochemical staining reactions performed on liver specimens from Cases 2, 5, and 7 did not reveal any significant abnormality. Electron microscopy of liver specimens obtained by aspiration biopsy from Cases 3 and 7 revealed large areas of agranular endoplasmic reticulum (39). Similar observations were made in livers of homozygous Gunn rats (39). The endoplasmic reticulum constitutes part of the microsomal fraction obtained by ultracentrifugation of liver homogenates. Glucuronyl transferase is associated with the microsomal fraction (1216). Elucidation of the relationship, if any, between the morphologic alteration in a constituent of the microsomal fraction and a defect in a microsomal enzyme requires further study. Upper gastrointestinal roentgenographic studies revealed an active duodenal ulcer in Cases 4 and 7 , and were normal in the other six patients. Oral cholecystography, or intravenous cholangiography, or both were normal in each patient.

7) Family studies. Cases 2, 4, and 17 are siblings, and 6 and 7 are first cousins. The paternal grandfather of Cases 2, 4, and 17 had chronic jaundice of approximately 40 years duration, but no further data are available regarding this man, who died in Italy at the age of 88 . There was no history of chronic jaundice in the other grandparents, parents, other siblings, children, aunts, uncles, or other first cousins of the eight patients.

Five of the 14 parents, 13 of 24 siblings, 1 of 2 children, and 16 of 22 aunts and uncles were examined. A complete blood count, serum cephalin cholesterol flocculation, serum bilirubin concentration, and menthol tolerance tests were normal in each of the family members except the father and paternal uncle of Cases 2, 4, and 17.

As indicated in Figure 1, the anicteric father and paternal uncle of Cases 2, 4, and 17 excreted 28 and 14 per cent, respectively, of ingested menthol in the urine as menthol glucuronide in the 5 hours after ingestion. Three hours after intravenous administration of $2.0 \mathrm{mg}$ bilirubin per $\mathrm{kg}$ of body weight, serum bilirubin concentrations were 5.2 and $4.8 \mathrm{mg}$ per cent, respectively, whereas control subjects and two siblings showed less than 1.5 mg per cent under similar circumstances (38). 


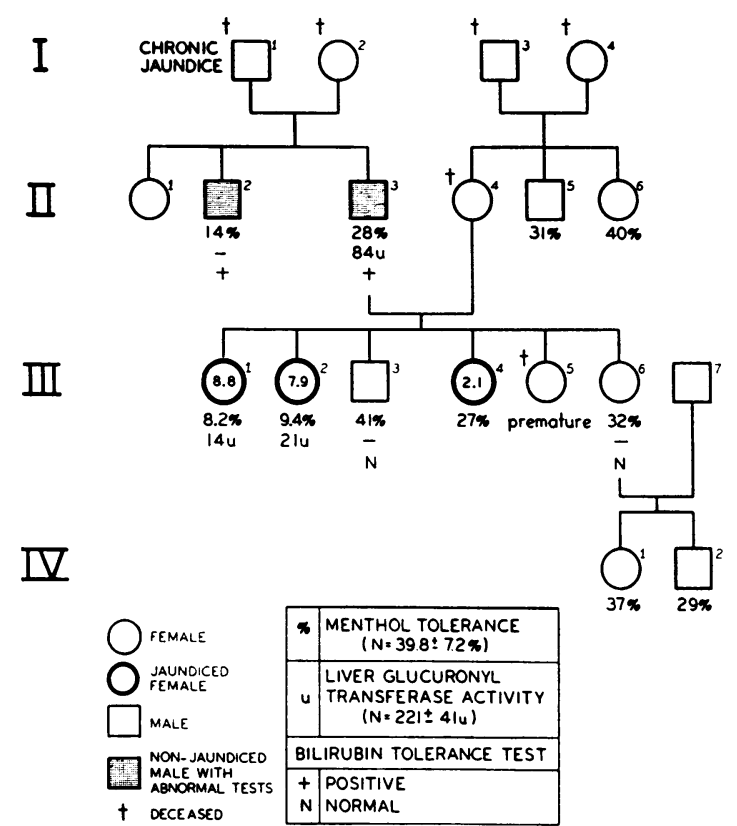

Fig. 1. Studies of glucuronide formation in Cases 2, 4, AND 17, AND THEIR FAMILY.

In a liver specimen obtained by aspiration biopsy from the father of Cases 2, 4, and 17, hepatic glucuronyl transferase activity was $84 \mathrm{U}$, or less than 40 per cent of the mean activity in the control group.

Chronic unconjugated hyperbilirubinemia in Cases 1 through 8 appears to result from a mechanism similar to that demonstrated in homozygous Gunn rats and infants with the Crigler-Najjar syndrome (40-47). In these disorders, lifelong unconjugated hyperbilirubinemia results from reduced formation of bilirubin glucuronide due to a deficiency in glucuronyl transferase activity (17, $44,45,48)$. There is no apparent compensatory increase in the formation of nonglucuronide bilirubin conjugates. Because bilirubin must be conjugated to be excreted in the bile and urine, unconjugated bilirubin accumulates in the plasma and tissues.

In Cases 1 through $8, a$ ) bile pigment production is not increased; in Cases 2 through $8, b$ ) urinary excretion of menthol glucuronide after ingestion of a test dose of menthol is significantly reduced as compared with that in normal subjects [Case 1 died before this test was performed (32)] ; c) hepatic glucuronyl transferase activity is reduced in homogenates or microsomal preparations of the patients' livers after suitable incubation with bilirubin, $o$-aminophenol, or 4-methyl umbelliferone as glucuronide receptors; $d$ ) no inhibitor of glucuronide formation was demonstrable in the liver homogenates in two cases; and $e$ ) the availability of UDPGA in specimens of liver from two of the patients appeared normal as evaluated by the ability of a boiled extract of the patients' livers to stimulate glucuronide formation by rat liver homogenates (15).

Cases 1 through 8 differ significantly, however, from cases of the Crigler-Najjar syndrome. Each of the observed cases of the Crigler-Najjar syndrome developed jaundice within several hours after birth and all but two died with kernicterus in the first year of life (41-43). Serum bilirubin concentrations ranged from 20 to $45 \mathrm{mg}$ per cent. Specimens of bile obtained from the duodenum were pale yellow, and contained only traces of unconjugated bilirubin (17). By way of contrast, in Cases 1 through 8 of this study, jaundice was first noted shortly after birth (four cases), during the first decade of life (three cases), and at age 30 (one case). Serum unconjugated bilirubin concentration ranged from 6.1 to $18.8 \mathrm{mg}$ per cent. Specimens of bile in four cases had normal color and contained abundant amounts of bilirubin glucuronide, perhaps explicable on the basis of reduced, but not absent, hepatic glucuronyl transferase activity. Case 1, who had kernicterus and lied at age 42 (32), has been considered by others as a case of the Crigler-Najjar syndrome who survived to adult life (48). This is a possibility, but the finding of bilirubin glucuronide in this patient's bile contrasts with the absence of bilirubin glucuronide described in the bile of infants with this syndrome (17).

In the Crigler-Najjar syndrome, the deficiency in glucuronide formation appears to be transmitted by a single autosomal recessive gene (46). The studies of the families of Cases 1, 3, and 5 through 8 were inadequate to permit speculation concerning inheritance of the observed defect in glucuronide formation. More adequate data are available in the family of Cases 2, 4, and 17-represented as III-1, III-2, and III-4, respectively, in Figure 1-and thus it is possible to speculate about the mode of inheritance of the defect in this family. An X-chromosome-linked, abnormal gene can be excluded by the apparent transmission of the defect from father, I-1, to his sons, II-2 and 
II-3. Transmission of the defect by a single autosomal recessive gene seems unlikely because of the rarity of the disease and the absence of consanguinity in the family, which make the probability very low that both parents of I-1 and the mother of the propositus were heterozygous for the abnormal gene. The most acceptable interpretation seems to be that the observed defect is transmitted as an autosomal dominant gene with incomplete penetrance and varied expressivity. Consequently, Cases 2, 4, and 17, as well as their anicteric father and paternal uncle. are assumed to be heterozygous for this gene, although the disease is fully expressed only in the daughters. In other cases, mild hyperbilirubinemia may result from defective glucuronide formation on the same genetic basis. Alagille (49) has proposed a similar possibility after studying a family in which three infants died with the Crigler-Najjar syndrome and one parent showed chronic unconjugated hyperbilirubinemia in much milder form. Additional data and studies of more families are required for further analysis of the pattern of genetic transmission of the observed defect and of the relationship, if any, between the present cases and the Crigler-Najjar syndrome.

The metabolic fate of much of the bile pigment in Cases 1 through 8 is unknown. Despite deficient conjugation of bilirubin with glucuronic acid, reduced fecal urobilinogen excretion, and normal erythrocyte life span, plasma concentration of unconjugated bilirubin (Table III), and the degree of clinical icterus remained relatively unchanged for many years.

Heterozygous Gunn rats (17) and the father and paternal uncle of Cases 2, 4, and 17 do not show hyperbilirubinemia; however, defective glucuronide formation has been demonstrated in vivo and in vitro $(17,45)$. After intravenous administration, unconjugated bilirubin disappears from the plasma of heterozygous Gunn rats at a significantly reduced rate as compared with that of homozygous normal litter mates (50). The father and paternal uncle of Cases 2, 4, and 17 showed similarly abnormal bilirubin tolerance tests. In both of these states, the abnormal bilirubin tolerance tests are presumably related to a reduced capacity to conjugate bilirubin before its excretion in the bile. It is reasonable to suspect that should any individual who is either heterozy- gous or homozygous for this defect be subjected to a disease process that results in increased production of bile pigment, pronounced unconjugated hyperbilirubinemia will occur.

\section{B. Patients with compensated hemolytic states (Cases 9-12)}

1) Clinical observations. The four cases were men from 18 to 68 years old; jaundice was first noted at $12,13,26$, and 60 years, and did not exceed 10 years' duration at the time of study. Each case showed jaundice limited to the sclerae. Three were asymptomatic. Case 12 periodically showed signs of congestive heart failure, and died of carcinoma of the lung 9 months after these studies were performed.

2) Serum bilirubin concentrations. These ranged initially from 1.8 to $3.4 \mathrm{mg}$ per cent. After addition of diazotized stulphanilic acid to each of the sera, only pigment A was identified on paper chromatograms. Serum bilirubin concentrations fluctuated for the group, from 0.3 to $4.6 \mathrm{mg}$ per cent. No clear relationship was observed between this fluctuation and coexistent illness. Case 10 was observed during an episode of influenza; serum bilirubin concentration increased from 2.1 to $4.1 \mathrm{mg}$ per cent during the acute illness and returned to $2.7 \mathrm{mg}$ per cent with recovery. Case 11 showed no significant change in serum bilirubin concentration before, during. and after a severe viral pneumonia. Increased signs of congestive heart failure were associated with increased serum bilirubin concentrations in Case 12.

3) Studies of the production of bile pigment. Estimations of hemoglobin concentration, hematocrit, red blood cell count, reticulocyte count, and erythrocyte osmotic fragility, and study of peripheral blood morphology performed at 4- to 6-week intervals for 6 to 12 months in each patient were consistently within normal limits. A Coombs test was normal in each patient. Specimens of bone marrow obtained by aspiration in each patient on two separate occasions were either normal or revealed slight erythroid hyperplasia ( $\mathrm{M}: \mathrm{E} 2: 1$ ) on morphologic examination. The half-time for the survival of the patients' erythrocytes after labeling with $\mathrm{Cr}^{51}$ ranged from 19 to 23 days. Quantitative urinary urobilinogen excretion was 
normal. Quantitative fecal urobilinogen excretion was increased in Case 10, and was in the high normal range in the three other cases.

4) Other studies. The results of in vitro assay of serum inhibitor factor activity, in vivo and in vitro studies of glucuronide formation, liver function tests, and radiologic examinations were normal. Histologic examinations of a liver specimen from biopsy in the light microscope were normal in each case, and an electron microscopic study was normal in Case 10.

5) Family studies. There was no history of chronic jaundice in the family members of any case. Eight parents, 13 grandparents, and 15 of 15 siblings were examined. Complete blood count, serum cephalin cholesterol flocculation, and bilirubin concentrations were normal in each.

Cases 9 through 12 have compensated hemolytic states of undetermined etiology as shown by shortened erythrocyte survival despite normal hemoglobin concentrations and reticulocyte counts. Decreased erythrocyte survival has been demonstrated in other patients with chronic unconjugated hyperbilirubinemia with normal hemoglobin concentrations and reticulocyte counts and in the absence of splenomegaly (51). Hemolysis occurring in the presence of normal liver function is only rarely associated with striking degrees of jaundice, presumably owing to the functional reserve of the liver in bilirubin metabolism (7). The normal liver theoretically ought to be able to excrete bile pigment resulting from the modest increase in erythrocyte destruction in these patients. Acquired but undemonstrated defects either in bilirubin transfer from plasma into the liver cells or in bilirubin conjugation are probably present in addition to increased erythrocyte destruction.

\section{Patients with posthepatitic unconjugated hy- perbilirubinemia (Cases 13-16)}

1) Clinical observations. Two cases were men. The patients' ages ranged from 19 to 21 years. At the time of study, each had had jaundice for 2 to 5 years.

None of the patients was known to have been jaundiced before the onset of acute viral hepatitis. The diagnosis of viral hepatitis was established by clinical history, appropriate laboratory tests, and morphologic study of liver biopsy specimens. Cases 13 and 14 were medical students in whom normal serum bilirubin concentrations were observed approximately 1 year before the onset of hepatitis. Chronic hyperbilirubinemia persisted in each patient after other signs and symptoms of hepatitis had disappeared.

2) Serum bilirubin concentrations. In these four cases, serum bilirubin concentrations ranged initially from 2.8 to $3.8 \mathrm{mg}$ per cent. After addition of diazotized sulphanilic acid to each serum, only pigment A was identified on paper chromatograms. From six to twelve estimations of serum bilirubin concentrations were made in each patient during a 12-month period. Hyperbilirubinemia was intermittent, and concentrations in the entire group ranged from 0.4 to $4.1 \mathrm{mg}$ per cent. Acute pyelonephritis in Case 16 was not associated with a significant change in the serum bilirubin concentrations before, during, and after the infection.

3) Other studies. The results of studies of bile pigment production, in vitro study of serum inhibitor factor activity, and in vivo and in vitro studies of glucuronide formation were normal in each case. The results of liver function tests were normal except for a repeatedly observed $3+$ serum cephalin cholesterol flocculation in Cases 13 and 14 and bromsulphalein retention of 14 and 18 per cent in Cases 14 and 15, respectively. Histologic examination of liver biopsy specimens in the light microscope was normal in Cases 16 and 17 and revealed nondiagnostic abnormalities in Cases 14 and 15. The abnormalities noted were an increase of fat in many liver cells and abundant round-cell infiltration in some of the portal triads. Histochemical studies of liver specimens obtained by aspiration biopsy in Cases 14 and 16 were normal. Electron microscopic study of a liver specimen in Case 16 revealed no abnormality in cellular ultrastructure.

4) Family studies. There was no history of chronic jaundice in the family members of any case. Eight parents, 6 grandparents, and 9 of 11 siblings were examined. Complete blood count, serum cephalin cholesterol flocculation, and serum bilirubin concentrations were normal in all, except a 10-year-old brother of Case 14 in whom the serum bilirubin concentration was repeatedly between 1.9 and $2.3 \mathrm{mg}$ per cent. Cases 14 through 
16 are presumed to have developed chronic unconjugated hyperbilirubinemia after documented episodes of viral hepatitis. Although a prolonged elevation of serum bilirubin in the indirect-reacting fraction has long been recognized as a consequence of viral hepatitis (52-56), the mechanism by which posthepatitic hyperbilirubinemia develops remains unclear.

\section{Patients with no etiologic factors or biochemical changes to account for observed chronic uncon- jugated hyperbilirubinemia (Cases 17-23)}

1) Clinical observations. Five of the seven patients were men. The patients' ages ranged from 17 to 48 years. Jaundice was present for 2 to 27 years at the time of study. Intermittent jaundice of the mucous membranes and sclerae was the only abnormal finding on repeated physical examinations. None of the cases gave a history suggestive of acute hepatitis. Two cases were asymptomatic. Cases 20 and 21 complained of chronic easy fatigability, weakness, headache, and postprandial nausea. Cases 22 and 23 were asymptomatic for 1 year after the onset of jaundice, when an erroneous diagnosis of chronic hepatitis was made in each case. They were treated with bed rest for approximately 4 months, and subsequently complained of chronic easy fatigability. It is my impression that the symptoms in each of these cases result from anxiety about the significance of chronic jaundice rather than from organic disease.

2) Serum bilirubin concentrations. At the time of study, these ranged from 0.7 to $2.0 \mathrm{mg}$ per cent. After addition of diazotized sulphanilic acid to each serum and subsequent paper chromatography, only pigment $\mathrm{A}$ was demonstrated. Table III presents the ranges in the concentrations observed over a 2-year period. Several cases described an increase in jaundice associated with ingestion of alcohol or coexistent infection. Case 22 voluntarily ingested ten ounces of whiskey, and the serum bilirubin concentration was $3.4 \mathrm{mg}$ per cent 24 hours later, or $1.5 \mathrm{mg}$ per cent over control values.

3) Other studies. The results of studies of bile pigment production, liver function tests, and histologic examination of liver specimens by light and electron microscopy were within normal limits. The patients' serum was not more inhibitory than normal serum to the formation of directreacting bilirubin by rat liver slices. As indicated in Table IV, the formation of direct-reacting bilirubin and 4-methyl umbelliferone glucuronide by liver slices or homogenates from Cases 18, 19, and 20 , when the glucuronide receptors were suspended in normal human plasma or in the patients' plasma, was not significantly different from the results of similar studies with normal human liver.

Menthol tolerance tests were normal in each case except Case 17, a sibling of Cases 2 and 4. Case 17 excreted 25 and 27 per cent of ingested menthol in the urine as menthol glucuronide on two separate occasions. These results do not exceed two SD from the mean excretion observed in the control group, and hence their significance is uncertain. An attempt was made to clarify this problem by administering twice the usual dose of menthol to Case 17 and two normal subjects. Each recipient complained of severe pyrosis, nausea, diarrhea, back pain, and burning discomfort in the rectum. In view of this demonstration of toxicity, no further attempts were made to increase the dosage of administered menthol.

Hepatic glucuronyl transferase activity was estimated in six of the patients with 4-methyl umbelliferone as a glucuronide receptor, and was within normal limits. The formation of directreacting bilirubin and $o$-aminophenol glucuronide was studied in homogenates of liver obtained at surgery in Cases 18, 19, and 20, and did not differ significantly from similar studies in a control group of subjects.

Bile was obtained either at surgery or by duodenal intubation in five patients and, after the addition of diazotized sulphanilic acid and subsequent paper chromatography, pigment $\mathrm{B}$ was found to account for approximately 60 to 90 per cent of the total dipyrrolazo pigments. Between 65 and 90 per cent of pigment $B$ was converted to pigment $\mathrm{A}$ after alkaline or beta glucuronidase hydrolysis.

4) Family studies. Six of 28 grandparents, 10 of 14 parents, and 15 of 19 siblings were examined. Each showed a normal complete blood count, serum cephalin cholesterol flocculation, and serum bilirubin concentration, except for the father of Case 19, the brother of Case 20, and a sister of Case 22. These three showed chronic unconjugated hyperbilirubinemia ranging from 1.5 to 2.7 
mg per cent in multiple determinations during a 6-month period.

In Cases 18 through 24, no etiologic factors or biochemical changes were observed that could account for the chronic hyperbilirubinemia, which was intermittent and with concentrations not exceeding $3.2 \mathrm{mg}$ per cent. In vivo studies of glucuronide formation have been performed in patients with chronic unconjugated hyperbilirubinemia not exceeding $3.3 \mathrm{mg}$ per cent with salicylamide (34) and $N$-acetyl-p-aminophenol (33) as glucuronide receptors. In neither study was a significant difference observed between the results obtained in jaundiced and control subjects. Both groups of investigators concluded that the observed chronic hyperbilirubinemia did not result from a defect in glucuronide formation, but may be related to abnormalities in the transport of bilirubin from plasma into the liver cell $(33,34)$. In other studies, however, after ingestion of menthol, patients with mild chronic unconjugated hyperbilirubinemia required a longer time than normal controls to excrete menthol glucuronide in the urine, although the total amount excreted during a 6-hour period was the same in both groups (57). The delayed excretion of menthol glucuronide suggests that some limitation in the rate of glucuronide formation may be present in these patients.

Virtually nothing is known about the mechanism by which bilirubin enters the liver cell. Sera of the 23 patients in this report did not inhibit the formation of direct-reacting bilirubin by rat liver slices more than did normal sera (Table II). In Cases 18, 19, and 21, glucuronide formation by patients' liver slices and homogenates, when the glucuronide receptors were suspended in normal human serum or in the patients' serum, was not significantly different from that in similar studies with normal human liver (Table IV). Within the limits of these experiments, the results fail to demonstrate, but do not exclude, an impairment in the transfer of the glucuronide receptors from serum in the incubation medium into the liver cells.

Chronic unconjugated hyperbilirubinemia of the degree seen in Cases 18 through 23 can result theoretically from a deficiency in glucuronide formation. For this reason, investigations involving the administration of various glucuronide receptors to patients with chronic jaundice are meaningful only if it is established that saturation of the conjugating mechanism has been obtained in normal subjects. This requires administration of the glucuronide receptor in increasing doses until excretion of the appropriate glucuronide is not increased in the normal subjects. If, under these circumstances, patients with chronic jaundice excrete less glucuronide than the normal subjects, a defect in glucuronide formation may exist. Unfortunately, the toxicity of the test material may limit this type of experiment; for example, the increased dosage of menthol in this study resulted in toxicity. An inability to demonstrate a difference between the jaundiced and control subjects does not necessarily indicate that the glucuronideforming system is normal. The limiting factor in the metabolism of the test substance may involve its rates of absorption, distribution, storage, and excretion, as well as the presence of several routes of metabolism.

In view of the finding that heterozygous Gunn rats, some adolescent and adult humans with chronic unconjugated hyperbilirubinemia, and nonjaundiced parents of children with the CriglerNajjar syndrome have defects in glucuronide formation, any glucuronide receptor used in the in vivo study of glucuronide formation ought to be capalle of differentiating these groups of humans and rats from appropriate controls.

\section{SUM MARY}

Clinical and hematologic studies, liver-function and histologic examinations, in vitro studies of serum inhibitor factor, and in vivo and in vitro studies of glucuronide formation were performed in 23 patients with chronic unconjugated hyperbilirubinemia without gross evidence of liver cell dysfunction or increased erythrocyte hemolysis. One hundred twenty-three of their family members were examined.

A deficiency in glucuronide formation activity was demonstrated in vivo and in vitro in an anicteric father of two chronically jaundiced children with a demonstrable defect in hepatic glucuronyl transferase activity. An anicteric paternal uncle demonstrated abnormal menthol and bilirubin tolerance tests. In this family, this defect appears to be transmitted as an autosomal dominant gene with incomplete penetrance and varied expressivity. 
Four patients had compensated hemolytic states that were not apparent until $\mathrm{Cr}^{51}$ erythrocyte survival studies were performed. Four patients had posthepatitic hyperbilirubinemia. In seven patients, no etiologic classification could be made.

Patients with chronic unconjugated hyperbilirubinemia without overt signs of hemolysis ought to be studied intensively and not relegated to a descriptive category until every method has been exhausted to determine the etiology of the jaundice. The terms "constitutional hepatic dysfunction," "physiologic hyperbilirubinemia," "Gilbert's disease," and so on, are best avoided, and when possible, the cases referred to in pathophysiologic terms.

\section{ACKNOWLEDGMENTS}

The author gratefully acknowledges the kind cooperation of the following physicians who referred patients for this study: A. Andreasen, J. Brenner, M. Erlandson, V. Herbert, H. Hodes, J. Hurd, G. Jervis, M. Kaska, L. Lucarrello, H. Michelsen, G. Miller, H. Rifkin, I. Schulman, B. Straus, V. Willner, and J. Wolf. The assistance of many members of the Departments of Medicine, Pediatrics, and Surgery of the Bronx Municipal Hospital Center, The Mount Sinai Hospital, the New York Hospital, and the Bronx Veterans Administration Hospital is gratefully appreciated. I am indebted to Miss Sonia Wolfson and Mrs. W. Furman for competent technical assistance; to Drs. A. Novikoff and E. Essner of the Department of Pathology for the histochemical studies and electron microscopy; to Dr. Salome Waelsch of the Department of Anatomy for guidance in interpretation of the results of the family studies; to Dr. Gordon Tompkins of the National Institutes of Health for suggesting the use of umbelliferone in the assay of glucuronyl transferase activity; to Dr. Kurt Isselbacher of the Department of Medicine, Harvard Medical School, for suggesting the use of the menthol tolerance test and for performing the test in several of the patients; to Prof. R. T. Williams of the St. Mary's Hospital Medical School for providing a sample of 4-methyl umbelliferone glucuronide; and to Mr. Felix Axelrad of the Fiber Chemical Corp. of Matawan, N. J., for a generous gift of 4-methyl umbelliferone.

\section{REFERENCES}

1. Gilbert, A., and Lereboullet, P. La cholémie simple familiale. Sem. méd. 1901, 21, 241.

2. Meulengracht, E. Icterus intermittens juvenilis. Klin. Wschr. 1939, 18, 118.

3. Alwall, N. On hereditary, non-hemolytic bilirubinemia. Acta med. scand. 1946, 123, 560.

4. Dameshek, W., and Singer, K. Familial nonhemolytic jaundice. Constitutional hepatic dysfunction with indirect van den Bergh reaction. Arch. intern. Med. 1941, 67, 259.
5. Van den Bergh, A. H. La recherche de la bilirubine dans le plasma sanguin par la reaction diazotique. Presse méd. 1921, 29, 441.

6. Comfort, M. W., and Hoyne, R. M. Constitutional hepatic dysfunction: clinical study of thirty-five cases. Gastroenterology 1944, 3, 155.

7. Arias, I. Bilirubin transport in the liver in Advances in Liver Disease, H. Popper and F. Schaffner, Eds. New York, Grune and Stratton, 1961.

8. Billing, B. H., Cole, P. G., and Lathe, G. The excretion of bilirubin as diglucuronide giving the direct van den Bergh reaction. Biochem. J. 1957, 65, 774.

9. Schmid, R. Direct-reacting bilirubin, bilirubin glucuronide, in serum, bile, and urine. Science 1956, 124, 76.

10. Talafant, E. Properties and composition of the bile pigment giving a direct diazo reaction. Nature 1956, 178, 312.

11. Isselbacher, K. J., and McCarthy, E. A. Studies on bilirubin sulfate and other nonglucuronide conjugates of bilirubin. J. clin. Invest. 1959, 38, 645.

12. Strominger, J., Maxwell, E., Axelrod, J., and Kalckar, $\mathrm{H}$. Enzymatic formation of uridine diphosphoglucuronic acid. J. biol. Chem. 1957, 224, 79.

13. Grodsky, G. M., and Carbone, J. V. The synthesis of bilirubin glucuronide by tissue homogenates. J. biol. Chem. 1957, 226, 449.

14. Schmid, R., Hammaker, L., and Axelrod, J. The enzymatic formation of bilirubin glucuronide. Arch. Biochem. 1957, 70, 285.

15. Arias, I. M., and London, I. M. Bilirubin glucuronide formation in vitro; demonstration of a defect in Gilbert's disease. Science 1957, 126, 563.

16. Isselbacher, K. J. Enzymatic mechanisms of hormone metabolism. II. Mechanism of hormonal glucuronide formation. Recent Progr. Hormone Res. 1956, 12, 134.

17. Axelrod, J., Schmid, R., and Hammaker, L. A biochemical lesion in congenital, non-obstructive, nonhaemolytic jaundice. Nature 1957, 180, 1426.

18. Arias, I., Johnson, L., and Wolfson, S. Biliary excretion of injected conjugated and unconjugated bilirubin by normal and Gunn rats. Amer. J. Physiol. 1961, 200, 1091.

19. Malloy, H., and Evelyn, K. Determination of bilirubin with the photo-electric colorimeter. J. biol. Chem. 1937, 119, 481.

20. Schmid, R. The identification of "direct-reacting" bilirubin as bilirubin glucuronide. J. biol. Chem. 1957, 229, 881.

21. Mollison, P. L., and Veall, N. The use of the isotope ${ }^{51} \mathrm{Cr}$ as a label for red blood cells. Brit. J. Haemat. 1955, 1, 62.

22. Watson, C., Schwartz, S., Soborov, V., and Bertie, E. Studies of urobilinogen. V. Simple method for quantitative recording of Ehrlich reaction as carried out with urine and feces. Amer. J. clin. Path. $1944,14,605$. 
23. Lathe, G. H., and Walker, M. Inhibition of bilirubin conjugation in rat liver slices by human pregnancy and neonatal serum and steroids. Quart. J. exp. Physiol. 1958, 43, 257.

24. Arias, I., and Wolfson, S. Studies of serum inhibitor factor in transient neonatal familial hyperbilirubinemia. In preparation.

25. Hsia, D. Y-Y., Dowben, R. M., Shaw, R., and Grossman, A. Inhibition of glucuronosyl transferase by progestational agents from serum of pregnant women. Nature 1960, 187, 693.

26. Williams, R. T. Studies in detoxication. 5. The preparation of $d$-glucurone from ammonium menthylglucuronate. Biochem. J. 1940, 34, 272.

27. Levvy, G., and Storey, I. D. E. The measurement of glucuronide synthesis by tissue preparations. Biochem. J. 1949, 44, 295.

28. Layne, E. Spectrophotometric and turbidimetric methods for measuring proteins in Methods of Enzymology, S. P. Colowick and N. O. Kaplan, Eds. New York, Academic Press, 1957, vol. 3, p. 451.

29. Ballentine, R. Determination of total nitrogen and ammonia in Methods of Enzymology, S. P. Colowick and N. O. Kaplan, Eds. New York; Academic Press, 1957, vol. 3, p. 987.

30. Ehrlich, J., Novikoff, A., Platt, R., and Essner, E. Hepatocellular lipofuscin and the pigment of chronic idiopathic jaundice. Bull. N. Y. Acad. Med. 1960, 36, 488.

31. With, T. K. Biologie der Gallenfarbstoffe. Stuttgart, Georg Thieme, 1960.

32. Jervis, G. A. Constitutional nonhemolytic hyperbilirubinemia with findings resembling kernicterus. Arch. Neurol. Psychiat. (Chic.) 1959, 81, 55.

33. Schmid, R., and Hammaker, L. Glucuronide formation in patients with constitutional hepatic dysfunction (Gilbert's disease). New Engl. J. Med. 1959, 260, 1310.

34. Barniville, H., and Misk, R. Urinary glucuronic acid excretion in liver disease and the effect of a salicylamide load. Brit. med. J. 1959, 1, 1337.

35. Weber, F. P. Remarks regarding chronic jaundice. Quart. J. Med. 1948, 17, 81.

36. Foulk, W. T., Butt, H. R., Owen, C. A., Whitcomb, F. F., and Mason, H. L. Constitutional hepatic dysfunction (Gilbert's disease) : its natural history and related syndromes. Medicine (Baltimore) 1959, 38, 25.

37. Snedecor, G. W. Statistical Methods. Ames, Iowa, Iowa State College Press, 1956.

38. Arias, I. Unpublished observations.

39. Novikoff, A. B., and Essner, E. The liver cell. Some new approaches to its study. Amer. J. Med. 1960, 29, 102.
40. Gunn, C. H. Hereditary acholuric jaundice in a new mutant strain of rats. J. Hered. 1938, 29, 137.

41. Crigler, J. F., and Najjar, V. A. Congenital familial nonhemolytic jaundice with kernicterus. Pediatrics 1952, 10, 169.

42. Childs, B., and Najjar, V. Familial nonhemolytic jaundice with kernicterus. Pediatrics 1956, 18, 369.

43. Rosenthal, I., Zimmerman, H., and Hardy, N. Congenital nonhemolytic jaundice with disease of the central nervous system. Pediatrics 1956, 18, 378.

44. Carbone, J. V., and Grodsky, G. M. Constitutional nonhemolytic hyperbilirubinemia in the rat: defect of bilirubin conjugation. Proc. Soc. exp. Biol. (N. Y.) 1957, 94, 461.

45. Arias, I. A defect in microsomal function in nonhemolytic acholuric jaundice. J. Histochem. Cytochem. 1959, 7, 250.

46. Childs, B., Sidbury, J., and Migeon, C. Glucuronic acid conjugation in patients with familial nonhemolytic jaundice and their relatives. Pediatrics 1959, 24, 903.

47. Johnson, L., Sarmiento, F., and Day, R. Studies of kernicterus in genetically jaundiced rats. J. Dis. Child. 1958, 96, 504.

43. Schmid, R. Hyperbilirubinemia in The Metabolic Basis of Inherited Disease, J. B. Stanbury, J. B. Wyngaarden, and D. S. Frederickson, Eds. New York, McGraw-Hill, 1960.

49. Alagille, D. Personal communication.

50. Arias, I. M., and Johnson, L. Studies of bilirubin excretion in normal and Gunn's rats. Clin. Res. 1959, 7, 291.

51. Conrad, M. E., Jr., Crosby, W. H., and Howie, D. L. Hereditary non-spherocytic hemolytic disease. Amer. J. Med. 1960, 29, 811.

52. Hult, $H$. 'Cholémie simple familiale' (Gilbert) and posthepatic states without fibrosis of the liver. Acta med. scand. 1950, suppl. 244, 1.

53. Nosslin, B. The direct diazo reaction of bile pigment in serum. Scand. J. clin. Lab. Invest. 1960, Suppl. 12, 49.

54. Kunkel, H. G., Labby, D. H., and Hoagland, C. L. Chronic liver disease following infectious hepatitis. I. Abnormal convalescence from initial attack. Ann. intern. Med. 1947, 27, 202.

55. Flood, C. A., and James, E. M. Clinical and pathological findings in prolonged hepatitis. Gastroenterology 1947, 8, 175.

56. Kalk, H., and Wildhirt, E. Die post-hepatitische Hyperbilirubiämie. Z. klin. Med. 1955, 153, 354.

57. Beck, K., and Kuhn, H. Beitrag zur Patholgenese der funktionellen Hyperbilirubinämie. Z. klin. Med. 1959, 155, 547. 